Portland State University

PDXScholar

$5-1978$

\title{
A Comparison Between a Clinical Sample of Parents and Non-parents, as Reflected by Their Scores on the MMPI
}

Thomas Kearney

Portland State University

Casey Wegner

Portland State University

Follow this and additional works at: https://pdxscholar.library.pdx.edu/open_access_etds

Part of the Applied Behavior Analysis Commons, and the Experimental Analysis of Behavior Commons Let us know how access to this document benefits you.

\section{Recommended Citation}

Kearney, Thomas and Wegner, Casey, "A Comparison Between a Clinical Sample of Parents and Nonparents, as Reflected by Their Scores on the MMPI" (1978). Dissertations and Theses. Paper 2686. https://doi.org/10.15760/etd.2682

This Thesis is brought to you for free and open access. It has been accepted for inclusion in Dissertations and Theses by an authorized administrator of PDXScholar. Please contact us if we can make this document more accessible: pdxscholar@pdx.edu. 


\title{
A COMPARISON BETWEEN A CLINICAL SAMPLE OF \\ PARFNTS AND NON-PARENTS, AS REFLECTED \\ BY THEIR SCORES ON THE MMPI
}

by

THOMAS KEARNEY AND CASEY WEGNER

\begin{abstract}
A practicum submitted in partial fulfillment of the requirements for the degree of
\end{abstract}

Master's in Social Work

Portland State University

1978 
TITLE: A COMPARISON BETWEEN A CLINICAL SAMPLE OF PARENTS AND NON-PARENTS, AS REFLECTED BY THEIR SCORES ON THE MMPI.

APPROVED BY:

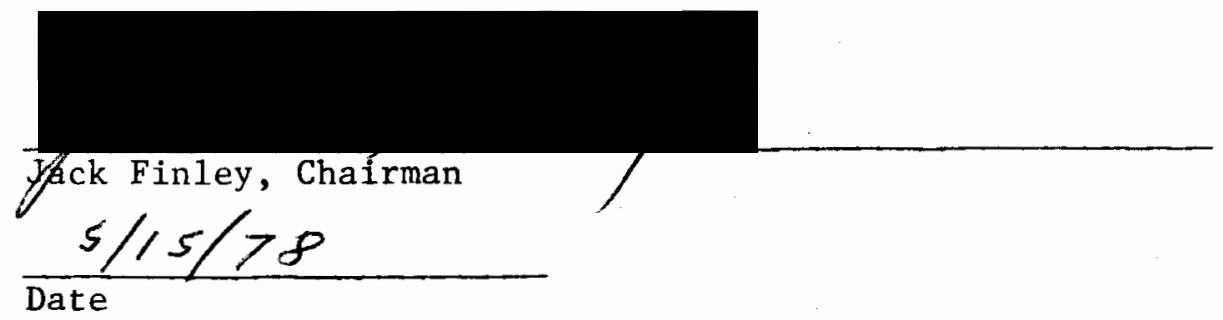


TABLE OF CONTENTS

PAGE

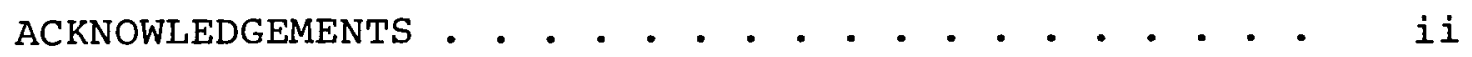

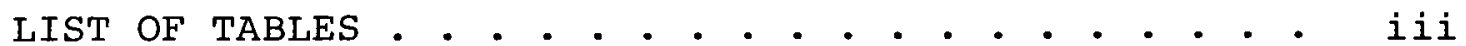

CHAPTER

I INTRODUCTION • • • • • • • • • • • • • • • 1

Incidence • • • • • • . . . . • . . 2

Characteristics of Childfree
Population . . . . . . . . 3

Development of Childfree Marriage . . 4

Social Pressure and Myths . . . . 5

Research on Marital Adjustment . . . 8

Research on Health and Mental

Health . . . . . . . . . 9

Assumptions and Hypothesis . . . . 10

II METHODS • . . . . . . . . . . . . 12

Operational Definitions . . . . . 15

Samples • • • • • . . . . . . . . 15

III DATA ANALYSIS . . . . . . . . . . . 17

IV CONCLUSION • • . . . . . . . • . . . 22

V SOURCES CONSULTED • • • • • • • • • • • . 27 


\section{ACKNOWLEDGEMENTS}

We wish to acknowledge, first of all, our own hard work and effort. However, this process has been made easier by the support and help we've received from our wives, friends, and colleagues. Specifically, we wish to give special thanks to: Delaunay Mental Health Clinic, Regional Research Institute, Jack Finley, Dean Clarkson, Nancy Koroloff, Susan Hines, Nancy Kearney, Ellen Wegner, Delores Morgan, and Don Pagono. 


\section{LIST OF TABLES}

TABLE

PAGE

I Non-Parent Distribution of Cases for $1 \frac{1}{2}$ Year Period Reviewed . . . . . . .

II Distribution of Non-Parents by Sex, Marital Status, IQ, and Education . . . . . 18

II Parent v. Non-Parent: MMPI Scale Means \& Standard Deviations . . . . . . . 19

IV Elevated Group Mean Scales on MMPI . . . . 19

V Significant $F^{\prime}$ s as Determined by Stepwise Discriminative Analysis . . . . . 20

VI Z Test for Goodness of Fit . . . . . . . . . 21 
CHAPTER I

INTRODUCTION

The area of childlessness, particulary voluntary childlessness, has been virtually ignored by most researchers. ${ }^{l}$ Pohlman claims to have been unable to find research which supports the popular idea that intentionally childless husbands and wives tend to be emotionally disturbed. However, he does note that he was able to find numerous statements from medical and social science publications which in various ways imply that the deliberately childless are usually maladjusted. 2

Some developmental models place importance on dealings with children for one's own psychosocial development. Erikson's seventh stage is "Generativity" defined as: "the concern in establishing and guiding the next generation." 3 It is presumed that a lack in this area leads to stagnation and

$1_{\text {J.E. Veevers, "Voluntary Childlessness: A Neglected }}$ Area of Family Study", The Family Coordinator, Vol. 22, No. 2, 1973, p. 199-206.

2 Edward Pohlman, "Childlessness, Intentional and Unintentional", The Journal of Nervous and Mental Disease, Vol. 151, No. 1, 1970, p. 9 .

${ }^{3}$ Erik Erikson, Childhood and Society (revised 2nd Ed) New York: W.W. Norton \& Company, Inc., 1963, p. 267. 
interpersonal impoverishment. Duvall's eighth, of nine stages, defines competency in bearing and raising children as one of the tasks of development. ${ }^{4}$ The implication from both of these models is that a child-free life style makes personal development past a certain point difficult or even impossible.

It is important to note that neither model is supported by research, as both are based solely on the personal observations of the authors. Our review of the literature failed to produce any research supporting the position that immature or maladjusted persons choose childfree life styles, or that childlessness hinders personal growth and development.

\section{Incidence}

The degree of childlessness in America and Canada has fluctuated greatly over the last eighty years. At the turn of the century 7.98 of the marriages were childless. How many of them were voluntary is unknown. The Depression Era brought with it a great increase in childfree marriages. Most studies city the incidence of childlessness at this time around 20\%. 5 One study, "The Indianapolis Study", reported

${ }^{4}$ J.E. Veevers, "The Social Meanings of Parenthood", Psychiatry, Vol. 36, No. 3, 1973, p. 305.

${ }^{5}$ Grabill, Wilson and Glick, Paul. "Demographic and Social Aspects of Childlessness: Census Data." The Milbank Memorial Fund Quarterly, Vol. 37, No. 1, 1959, p. 60 . 
$40 \%$ voluntary childfree marriages in that community from 1927 to 1941.6

From WWII into the late $1960^{\prime} \mathrm{s}$ the number of childless marriages greatly decreased. Recently, however, "voluntary childlessness in the adult population increased markedly, from $1.3 \%$ in 1967 to $3.9 \%$ in 1971, according to Census Bureau figures." 7

\section{Characteristics of Childfree Population}

Several general characteristics of the childfree couple have been noted by recent researchers. ${ }^{8}$ Childlessness is nearly twice as great in urban as in rural farm areas. In rural areas those devoted to non-farming have consistently greater frequencies of childiessness than those that are primarily farming communities.

The younger a woman is at the time of her first marriage, the less likely it is that she'll remain childless. This relationship has generally been attributed to physiological factors. However, studies by Veevers conclude that at least for women who marry prior to thirty-five,

${ }^{6}$ Freedman, R., Whelpton, P., \& Campbell, A. Family Planning, Sterility and Population Growth. New York: McGraw Hill Book Company, Inc., 1959, p. 46.

${ }^{7}$ Peck, E. \& Senderowitz, J. (eds.) Pronatalism. New York: Thomas Y. Crowell Company, 1974, p. 253.

${ }^{8}$ J.E. Veevers, "Rural-Urban Variation in the Incidence of Childlessness", Rural Sociology, Vol. 36, No. 4, 1971, p. 547 . 
psychological disinclination to parenthood may be the major factor explaining this correlation between age at first marriage and childlessness. 9

Those childless couples studied generally lacked a strong religious affiliation. They tend to be in a relatively high socio-economic class, and are highly educated. In addition,

The major components of the child-free life style include dyadic withdrawal and the idealization of the wife-husband relationships; occupational commitment; the quest for experience; the absence of generativity; and egalitarian role relationships which minimize female-male differences. 10

Development of the Childfree Marriage

Veevers describes a two tract model that couples use towards becoming and viewing themselves as childless. 11 Tract one involves the couple's entry into matrimony with a clear childlessness clause as part of the marriage contract. One-third of the childfree marriages noted appeared to follow this pattern.

${ }^{9}$ J.E. Veevers, "Childlessness and Age at First Marriage", Social Biology, Vol. 18, No. 3, 1971, p. 294.

10 J.E. Veevers, "Life style of Voluntarily Childless Couples." Abstract of a paper presented to 1974 annual meeting of the National Council of Family Relations, Women Studies Abstracts, Vol. 3, No. 4, 1974, p. 49.

${ }^{1}{ }^{1} \mathrm{~J} . \mathrm{E}$. Veevers, "Voluntarily Chilaless Wives: An Exploratory study" (article from Peck and Senerowitz, eds), Pronatalism, New York: Crowell Co., 1974, p. 297-299. 
The more frequent route noted was the postponement model, which consists of four stages, and was noted in about two-thirds of childfree marriages. The first stage involves postponement for a definite period of time. At this point, childfree couples are indistinguishable from those who will become parents. The postponement is often attributed to specific reasons, such as finishing school, or travel, and usually there is some commitment to have children when conditions are right.

The second stage involves a shift from a definite period of time to indefinite postponement. The couple still are committed to the idea of parenthood, only now they are more vague as to when it will happen.

The third stage involves open acknowledgement of the possibility that in the end they may remain permanently childless. During this time the pros and cons of having children are openly discussed, as is the comparison of their life style with peers who are raising children. At this stage a definite decision is not finalized.

The fourth stage involves the definite conclusion that they are never going to have children. Childlessness becomes a permanent rather than transitory state, and generally involves a recognition of an event that has already occurred.

\section{Social Pressure and Myths}

It has been noted that childless marriages comprise a minority, voluntary childlessness an even smaller one, and 
those with a clear childfree contract even smaller yet. American society has been portrayed as child centered or "pronatalist". Pressure for procreation appears to vary over time. 12 Childlessness for the first nine months of marriage is often seen as desirable, for it quiets any question that the couple were forced to marry. Generally, after the first year of marriage, pressure gradually begins to mount until it peaks in the third or fourth year. After the fifth or sixth year the pressure begins to decrease.

It is apparent that couples who choose a childfree life style must contend with deviating from one of the most accepted norms in our society. It is assumed that social pressures are a major reason contributing to the development of the postponement model, which clearly is a defensive strategy which minimizes the external and internal conflict which would result from a final commitment to childlessness.

LeMasters notes four prevalent myths regarding childlessness that reflect the general negative view noted earlier. 13 The first is that nonparenthood is a flouting of religious authority and immoral. There are numerous accounts in the Bible of the curse of childlessness, while birth is

12 Peck, E. \& Senderowitz, J. Pronatalism, New York: Thomas Y. Crowell Company, 1974, p. 256.

${ }^{13}$ E.E. LeMasters, Parents in Modern America: A Sociological Analysis, Homewood, Ill.: The Dorsey Press, 1970, p. 30-38. 
portrayed as being a blessing from heaven. Veevers notes, "...all of the major religious groups interpret procreation as a moral obligation necessary for fulfillment of religious ends and purposes of marriage." 14 The Roman Catholic Church's position goes so far as to state that marriage with the intent of childlessness is not valid in the eyes of God.

The second myth noted was that nonparenthood is unnatural, in that it is assumed that a strong parental instinct exists. An argument against the supremacy of an innate drive to parenthood is the degree of variability within and among cultures. It was noted in American during the Depression childlessness rose dramatically. Mead, in her study of the Mundugumor society found a people where, "women detest bearing and rearing children, and men detest their wives for being pregnant."15 Mehlan, writing in 1965, cites Romania's childlessness at $28 \% .16$ It appears that reproduction is not simply the result of innate drives, but that motives for reproduction are subject to modification by culture, experience and social learning.

14 J.E. Veevers, "The Social Meaning of Parenthood", Psychiatry, Vol. 36, No. 3, 1973, p. 292.

15 J.E. Veevers, "The Social Meaning of Parenthood," Psychiatry, Vol. 36, No. 3, 1973, p. 296.

16 William F. Kenkel, The Family in Perspective, New York: Appleton-Century-Crofts, Inc., 1960, p. 77. 
The third myth noted is that parenthood is the reason and meaning of marriage. The converse is that childlessness destroys the meaning of marriage and negatively effects the couple's marital adjustment.

Studies have found the relationship between the number of children in a marriage and marital adjustment to be positive (Davis, 1929), negative (Reed; Christensen \& Philbrick; Feldman), curvilinear (Blood \& Wolfe; Landis \& Landis), and non-existent (Burgess \& Cottrell; Locke; Prince)... There is some evidence that the crucial variable in the relationship of childbearing to marital adjustment is the couple's ability to control their fertility, and to achieve the exact number of children they consider desirable, regardless of whether that involves a large family or no children at all.17

A fourth myth noted was that nonparenthood is associated with abnormal mental health, immaturity or emotional maladjustment. These myths appear to function to channel

social pressures towards having children.

When a social function is relatively rigorous, as parenthood seems to be in our society, a rich ethos or romantic folklore evolves to make sure that the role is note avoided by most adults. In the case of parenthood, all sorts of sanctions are provided to encourage men and women to have children and rear them. 18

Research on Marital Adjustment

Two previous studies of marital adjustment which utilized the MMPI, indicate there are significant sex differences

17 J.E. Veevers, "The Social Meaning of Parenthood", Psychiatry, Vol. 36, No. 3, 1973, p. 301-302.

${ }^{18}$ E.E. LeMasters, Parents in Modern America: A Sociological Analysis, Homewood, Ill.: The Dorsey Press, 1970, p. 30 . 
between couples who seek marital counseling, irrespective of their parental status.

For wives, marriage failure was associated with endorsement of a tremendously broad range of symptoms from psychosomatic or neurotic complaints to psychotic characteristics... The husbands manifest a more homogeneous dimension of psychopathology like an alienated character disorder and potentially more indicative of sociopathic or psychotic disturbance than neurotic complaints. 19

Pd is the most powerful discriminator of maritally conflicted couples. Marriage counselees are more disturbed than normals, but less disturbed than psychiatric inpatients. Maritally conflicted wives are more disturbed than their husbands. 20

Research on Health and Mental Health

Malmquist and Kaij report a study of twins in Sweden, comparing those women who had children with their co-twins who did not. They found no differences between them before the first child, but after birth the mothers, "exhibited a significantly higher psychiatric, somatic and total morbidity compared with their co-twins." 21

${ }^{19}$ Murstein, B. \& Glaudin, V. "The Use of the MMPI In the Determination of Marital Maladjustment." Journal of Marriage and the Family, Vol. 30 , No. 4, 1968, p. 654 .

20 Arnold, P. "Marriage Counselee MMPI Profile Characteristics with objective Signs that Discriminate Them From Married Couples in General." Dissertation Abstracts International, 8B, Feb., 1975, 4250 .

${ }^{21}$ Malmquist, A. \& Kaij, L. "Motherhood and Childlessness in Monozygous Twins: Part 2, The Influence of Motherhood on Health", British Journal of Psychiatry, Vol. 118, No. 542,1971, p. 28 . 
Another study, done in the Netherlands, found that, "Parents are not happier than non-parents, that they do not have fewer psychosomatic complaints, and that parents feel less healthy than non-parents do." 22

Assumptions and Hypothes is

Though it is not extensive or definitive, the research available indicates that non-parents may have less general health and mental health problems than parents. This contradicts the prevalent negative view of childless couples as sick, emotionally disturbed or developmentally retarded. This investigation attempts to first discover whether a clinical sample of parents and non-parents may be distinguished on the basis of their scores on the MMPI. If significant differences emerge between parents and non-parents, the second stage of the investigation is to note the direction of the differences and determine whether any inferences can be drawn regarding the relative psychopathology of the two groups.

It is assumed that there is a difference, psychologi- $V$ cally and socially, between having no children and having one or more children. The addition of each person to the marital system creates many and complex changes in the dynamics of that system. Speculation regarding differences

22 Veenhoven, R. "Is there an innate need for children?" European Journal of Social Psychology, Vol. 4, No. 4, 1974, p. 500 . 
between non-parents and parents before parenthood is achieved must remain open, as no research to date adequately deals with the question of intent.

On the basis of the research available, some tentative hypotheses may be proposed regarding the area and direction of differences between the two groups. First, from the Swedish study it would be predicted that generally parents, or more accurately mothers, would have more psychiatric problems than non-mothers. Thus the general overall prediction would be that for each clinical scale on the MMPI, parents would have significantly more elevated scores than non-parents.

The second hypothesis is that parents and non-parents would differ on subjective ratings of general health. Specifically, it would be predicted that parents would score significantly higher on scale number 1, Hypochondria.

Based on the information available on the incidence and characteristics of childless couples, it may be hypothesized that childless couples are generally less conventional than parents. It may be predicted that non-parents would score significantly higher on scale number 4 , Pd.

The fourth hypothesis is that non-parents are more introverted than parents. Specifically, it would be predicted that non-parents would score significantly higher on scale number 0 , Social Introversion.

The characteristic of egalitarian role relationships in childless couples would predict a minimization of 
male-female differences by them. Hence it would be predicted that on scale number 5, Male-Female, of the MMPI, non-parents would score significantly lower than parents. 
CHAPTER II

METHODS

Due to time and monetary resource limitations, this investigation utilized already existing data. We were interested in using the MMPI, due to the association between some of its scales and the already available information regarding possible differences between parents and non-parents. An out patient, private, mental health clinic located in North Portland, Delaunay Mental Health Clinic provided the source for our data. Here for approximately an 18 month period, from June of 1972 to November of 1973, the MMPI was routinely administered to all initial interviewees. In addition, during this period the Shipley I. Q. was also routinely given, and reporting practices regarding information to be given in the charts was somewhat standardized. At no other time period in the history of the agency was the MMPI administered with as much consistency; and therefore, even though social history information appears to be more completely available since the period under study, this period was selected because of the primacy of the MMPI data. In addition to the MMPI and Shipley I. Q., a standardized face sheet was utilized which contained information on the following variables: sex, marital status, number of dependents, dob, income, education, and ethnic group. Other information available in 
the charts was determined to not be present with sufficient consistency to be utilized. (The charts were filed by case number, and confidentiality was maintained by recording all data by case number.) The data search procedure involved a screening of each individual chart opened during the time period given, and then recording under the case number the data identified above. Children, who were coded separately, were eliminated from the chart review. Though standard reporting procedures existed, it was found that the amount of information provided was not uniform, necessitating a complete review of all information in the chart in order to validate and complete the data desired.

Once the case review was completed, the data was organized, and the different variables examined to determine how completely they were represented.

A total of 345 charts were reviewed, 281 or $81 \%$, contained an MMPI profile and were completed for our purposes. It appeared that most charts lacking an MMPI generally contained very little information, often only the face sheet; hence, there is no basis on which to determine if a particular sub-population was over represented, though this seems unlikely. It is assumed that the charts lacking an MMPI were randomly distributed among incoming clients (probably mainly due to staff).

The other variables were also not completely consistent, though those cases with an MMPI tended to generally have the other information also. 
Operational Definitions

Parents were operationally defined as married adults who had one or more minor dependents living with them at the time of the initial interview. Generally the children were the natural offspring of one of the adults.

Non-parents are not as easy to operationally define. As noted earlier, intent is an important component of an ideal definition of childlessness. However, information regarding intent was not available to this investigation. Also, information was unavailable regarding whether the nonparents were biologically able to have children. With these limitations, and for the purposes of this study, it was determined that a simplified definition of childlessness would be employed. Childlessness was originally operationally defined as adults who have been married for at least five years, and have not had any children, and are not currently expecting a child nor have adopted a child. However, due to the lack of any subjects who met this criteria, the operational definition was changed to adults married for at least two years, without children, and not currently expecting, nor in the process of adopting a child.

Samples

of the 345 cases reviewed a total of 24 cases or 6.98 met the second criteria for childlessness.

The parent sample was selected by the following procedure. First, the non-parent sample was stratified in three 
groups on the basis of score on the Shipley I. Q. The sex and marital status (i.e. married, divorced, or separated) and education (i.e. less than high school degree, high school degree, more than high school degree) of each non-parent was noted. Then the parents were stratified in the same manner as non-parents on the basis of Shipley I. Q., education level, marital status, and sex. Those subjects who matched the non-parents became part of the selection group of parents. In a few cases there was a one to one correspondence between the groups, so that only one parent matched on all the criteria and that case was selected. In many cases more than one parent matched all the criteria, and one of these was randomly selected. By matching on marital status, IQ, education, and sex, these potential confounding variables were controlled.

After the samples were determined, a statistical computer analysis (Stepwise Discriminative Analysis) was performed. First analysis was between parents and non-parents, then between male and female parents, male and female nonparents, non-parent and parent males, and finally non-parent and parent females. In addition, each individual case was analyzed and classified on the basis of a total profile. A $\mathrm{Z}$ test for goodness of fit to appropriately classify cases was also performed. 
CHAPTER III

DATA ANALYSIS

Data on non-parents is found in Tables I and II. Three hundred and forty-five adults sought help during a $1 \frac{1}{2}$ year period. None of these adults fit our initial definition of non-parent. Thirty-five cases did fit the alternative definition.

TABLE I

NON-PARENT DISTRIBUTION OF CASES FOR

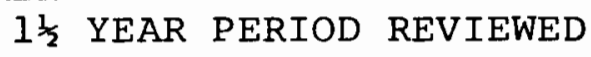

$\begin{array}{lcr}\text { CASES } & \text { NUMBER } & \text { OF TOTAL } \\ \text { TOTAL } & 345 & 100 \% \\ \text { COMPLETED FILES } & 281 & 81 \% \\ \text { NON-PARENT } & & \\ \text { A) DEFINITION } 1 & 0 & \\ \text { B) DEFINITION 2 } & 24 & 6.9 \%\end{array}$

Table II shows the distribution of our 24 non-parent subjects. The parent sample, in this study, was randomly drawn from matched groupings with the non-parents on these variables. IQ levels were determined by dividing the group's range of scores on the Shipley I. Q. into thirds. Education and marital status were obtained from self-reported responses given at the time of admission. 
TABLE II

DISTRIBUTION OF NON-PARENTS BY SEX, MARITAL
STATUS, IQ, AND EDUCATION

$\mathrm{T} 1 / 3 * * *$

$E L$ * EM EH
$\mathrm{MI} / 3$

EL EM EH
$\mathrm{BI} / 3$

EL EM EH

All subjects also filled out MMPI's. These MMPI's are the dependent variables. Table III displays the group MMPI means and standard deviations for both parents and nonparents. An individual MMPI scale score of more than 70 is often referred to as an elevated score, as it is two standard deviations from the instrument's mean scale score. Table IV exhibits all elevated group mean scales. The groupings analyzed were male and female non-parents, male and female parents, male non-parents, male parents, female nonparents, and female parents. 
TABLE III

PARENT V. NON-PARENT: MMPI SCALE MEANS \& STANDARD DEVIATIONS

SCALE

MEANS

STANDARD DEVIATIONS

\begin{tabular}{|c|c|c|c|c|}
\hline & $P$ & $\mathrm{NP}$ & $\mathrm{P}$ & $\mathrm{NP}$ \\
\hline $\mathrm{L}$ & 47.375 & 47.583 & 6.020 & 4.568 \\
\hline$F$ & 62.958 & 64.042 & 8.859 & 12.422 \\
\hline $\mathrm{K}$ & 52.333 & 49.083 & 10.374 & 9.283 \\
\hline $\mathrm{Hs}$ & 63.333 & 55.708 & 13.570 & 12.513 \\
\hline $\mathrm{D}$ & 72.542 & 69.208 & 18.657 & 20.041 \\
\hline Hy & 67.042 & 62.208 & 11.675 & 10.855 \\
\hline $\mathrm{Pd}$ & 72.000 & 67.417 & 10.082 & 15.254 \\
\hline $\mathrm{Mf}$ & 55.250 & 55.833 & 13.398 & 14.577 \\
\hline $\mathrm{Pa}$ & 63.500 & 62.458 & 10.194 & 12.507 \\
\hline Pt & 66.792 & 65.500 & 14.967 & 16.894 \\
\hline Sc & 70.083 & 68.000 & 17.832 & 16.333 \\
\hline $\mathrm{Ma}$ & 60.667 & 57.333 & 14.291 & 10.901 \\
\hline Si & 58.792 & 62.875 & 12.724 & 11.615 \\
\hline
\end{tabular}

TABLE IV

ELEVATED GROUP MEAN SCALES ON MMPI

$\begin{array}{cllllllr}\text { GROUP } & \text { SCALE } & \text { MEAN } & \text { GROUP } & \text { SCALE } & \text { MEAN } \\ \text { P } & 2 & \text { D } & 72.542 & \text { NP-F } & 8 & \text { SC } & 69.333 \\ \text { P } & 4 & \text { Pd } & 72.000 & \text { P-M } & 2 & \text { D } & 79.000 \\ \text { P } & 8 & \text { SC } & 70.083 & \text { P-M } & 4 & \text { Pd } & 71.083 \\ \text { NP } & 2 & \text { D } & 69.208 & \text { P-M } & 8 & \text { SC } & 71.000 \\ \text { NP-M } & 2 & \text { D } & 73.750 & \text { P-F } & 4 & \text { Pd } & 72.917 \\ \text { NP-M } & 4 & \text { Pd } & 69.083 & \text { P-F } & 8 & \text { SC } & 69.167\end{array}$

A Stepwise Discriminant Analysis was performed on the data. The results of this analysis are reported in Table V. Briefly, the analysis shows that our parent and non-parent groups can be significantly differentiated on the basis of scale 1 alone. In addition, these two groups can also be significantly differentiated by the combination of scales $1 \& 0$, plus $1,0, \& 4$. In comparing males v. females, both the parental and non-parental groups scored significantly 
different on scale 5 Mf. This difference provides added support to the validity of scale 5 to differentiate between males and females. When females were compared no one scale alone was able to distinguish the parents from the nonparents. However, scales 1 \& 0 in alliance were able to distinguish between these two groups. There was no individual scale or combination of scales that significantly differentiated our male subjects.

\section{TABLE V}

\section{SIGNIFICANT F'S AS DETERMINED BY STEPWISE DISCRIMINANT ANALYSIS}

\begin{tabular}{|c|c|c|c|c|c|c|}
\hline \multicolumn{2}{|c|}{ GROUP } & SCALE & \multicolumn{2}{|c|}{ MEAN } & \multirow{2}{*}{$\begin{array}{c}F \\
4.0955\end{array}$} & SIGNIFICANCE \\
\hline $\mathrm{P} \quad \mathrm{V}$ & NP & $1 \mathrm{Hs}$ & $\begin{array}{l}\text { (P) } \\
(\mathrm{NP})\end{array}$ & $\begin{array}{l}63.333 \\
55.708\end{array}$ & & $\begin{array}{c}\operatorname{df}(1,46) .05= \\
4.056\end{array}$ \\
\hline $\mathrm{P} \quad \mathrm{V}$ & NP & $\begin{array}{ll}1 & \mathrm{HS} \\
0 & \mathrm{Si}\end{array}$ & $\begin{array}{l}(\mathrm{P}) \\
(\mathrm{NP})\end{array}$ & $\begin{array}{l}58.792 \\
62.875\end{array}$ & 6.3100 & $\begin{array}{c}\mathrm{df}(2,45) \cdot 05= \\
3.21\end{array}$ \\
\hline $\mathrm{P} \quad \mathrm{V}$ & NP & $\begin{array}{ll}1 & \mathrm{Hs} \\
& \& \\
0 & \mathrm{Si}^{*} \mathrm{Pd}\end{array}$ & $\begin{array}{l}(\mathrm{P}) \\
(\mathrm{NP})\end{array}$ & $\begin{array}{l}72.000 \\
67.417\end{array}$ & 4.30892 & $\begin{array}{c}\mathrm{df}(3,44) .05= \\
2.824\end{array}$ \\
\hline$(F)$ & $\begin{array}{lll}P & \mathrm{~V} P \\
, & \end{array}$ & $\begin{array}{l}1 \\
0\end{array}$ & $\begin{array}{l}(P) \\
(N P) \\
(P) \\
(N P)\end{array}$ & $\begin{array}{l}59.667 \\
53.333 \\
56.500 \\
63.833\end{array}$ & 4.15995 & $\begin{array}{c}\mathrm{df}(2,21) .05= \\
3.4\end{array}$ \\
\hline$(\mathrm{P})$ & $M \quad F$ & Mf & $\begin{array}{l}(\mathrm{M}) \\
(\mathrm{F})\end{array}$ & $\begin{array}{l}64.417 \\
46.083\end{array}$ & 21.0086 & $\begin{array}{c}\mathrm{df}(1,22) .05= \\
4.30\end{array}$ \\
\hline (NP) & $M \vee F$ & Mf & $\begin{array}{l}(\mathrm{M}) \\
(\mathrm{F})\end{array}$ & $\begin{array}{l}64.917 \\
46.750\end{array}$ & 14.9849 & $\begin{array}{c}\operatorname{df}(1,22) .05= \\
4.30\end{array}=$ \\
\hline
\end{tabular}

Each individual case was analyzed and classified on the basis of a total profile. This was accomplished by weighting 
each scale by its maximum ability to differentiate among the groups. Then each individual case was evaluated by those functions and assigned to the group it best fit. The results are reported in Table VI. A $\mathrm{Z}$ test was computed to assess the goodness of fit. The results $(Z=2.42)$ show that $P$ and NP's (combined male and female group) could be distinguished at the 5\% level of significance $(z=1.96)$. The MMPI profile could correctly distinguish between female parents and female non-parents $75 \%$ of the time $(\mathrm{z}=2.77)$, and this finding was significant at the $1 \%$ level $(z=2.59)$. The same results were obtained with male parents v. male non-parents.

TABLE VI

Z TEST FOR GOODNESS OF FIT

GROUP CORRETLY CLASSIFIED AS Z *

P NP $\quad$ \% OF TOTAL

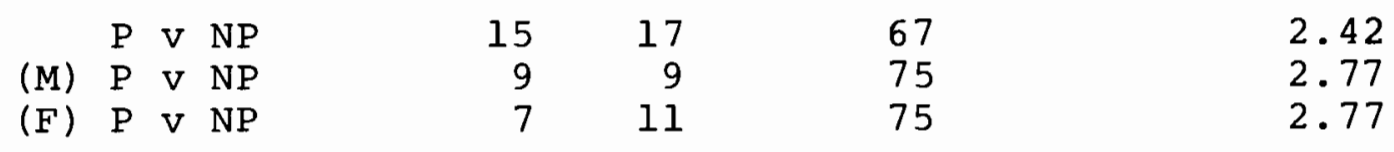

$1 \%$ level of significance is 2.59

5 응 level of significance is 1.96 
CHAPTER IV

CONCLUSIONS

A basic hypothesis of this study is that psychological differences exist between parents and non-parents, and would be reflected in their MMPI profiles. This hypothesis was clearly supported in our clinical sample. The results of the stepwise discriminant analysis reflect that our parents and non-parents can be significantly differentiated $(p<.05)$ on the basis of scale 1, Hypochondriasis, alone (parent mean 63.333, non-parent mean 55.708, F 4.0955, df 1,46). In addition the results show that our parents and non-parents can be differentiated $(p<.05)$ by the combination of scale 1 and scale 0, Social Introversion ( $F$ 6.310, df 2,45). Finally, the combination of scale 1,0 , and 4 , significantly differentiated our parent and non-parent groups ( $\mathrm{p}<.05, \mathrm{~F} 4.30892$, df 3,44$)$. Further support for the hypothesis is provided by the $\mathrm{z}$ test for goodness of fit. In 15 out of 24 cases, an MMPI profile actually completed by a parent was correctly identified as such by a procedure which analyzed the correspondence between the score on each scale and that scale's relative ability to differentiate among our two groups. By the same procedure, in 17 of 24 cases, an MMPI profile actually completed by a non-parent was correctly identified as such. Therefore, 32 of 48 cases, or $67 \%$, were correctly 
identified. The $\mathrm{z}$ test for goodness of fit reflected that the MMPI profiles of our parents and non-parents could be distinguished at the .05 level ( $\mathrm{z}$ 2.42).

The combinations of scales $1,0 \& 4$, which discriminated between our parents and non-parents included those scales on which the two groups were predicted to differ. It was predicted that parents would score significantly higher than non-parents on scale 1, Hypochondriasis. The mean for parents on this scale was 63.333, the mean for non-parents was 55.708. This difference in means was significant at the .05 level (F 4.0955, df 1,46). Thus our results support previous research (Malmquist \& Kaij, Veenhoven) 23 which indicated that parents subjectively rate their health more poorly than non-parents.

Another hypothesis was that non-parents would score significantly higher than parents on scale 0, Social Introversion. The mean for non-parents was 62.875 , the mean for parents was 58.792. Although this difference was not by itself significant, it was in the direction predicted, and the scale did, in combination with scale 1, discriminate between the two groups.

23 Malmquist, A. \& Kaij, L. "Motherhood and Childlessness in Monozygous Twins: Part 2, The Influence of Motherhood on Health" British Journal of Psychiatry, Vol. 118, No. $542,1971, \mathrm{p} .28$.

Veenhoven, R. "Is There an Innate Need for Children?" European Journal of Social Psychology, Vol. 4, No. 4, 1974, p. 500 . 
Another hypothesis was that non-parents would score significantly higher than parents on scale 4, Psychopathic Deviate. This hypothesis was not supported by our data. A probable confounding variable was marital conflict. Previous research (Arnold) 24 was noted, which indicated that elevated scores on this scale identifies marital conflict. Another hypothesis not supported by our data was that nonparents would score significantly lower than parents on scale 5, Male, Female.

The second part of this investigation examines the inferences that may be drawn from our data about the relative psychopathology of our two groups. It was reported that there was only one scale that by itself significantly discriminated between the parent and non-parent groups. While parents scored higher on scale l, Hypochondriasis, their group mean, 63.333, does not represent a clinically elevated score, conventionally defined by a $T$ score of 70 or above. Hence, although a significant difference exists for our two groups on this scale, it is not possible to infer a difference in relative psychopathology.

of those scales which in combination with scale 1 discriminated between our two groups, only scale 4, Psychopathic Deviate, reflected scores in the elevated range. However,

24 Arnold, P. "Marriage Counselee MMPI Profile Characteristics With objective Signs that Discriminate Them from Married Couples in General" Dissertation Abstracts International, 8B, Feb., 1975, 4250 . 
the difference in groups means was not significant, and the elevated scores for both groups probably reflect a significant degree of marital conflict in our clinical sample. Thus, our data provides no basis on which to infer that our parents and non-parents differ in regards to relative psychopathology, as indicated by scores on the MMPI.

The population from which we sampled, all adults who completed an initial interview at an out-patient mental health clinic during a specific time period, introduces a bias and obviously limits the generalizability of our results. Although we do not intend to generalize beyond our particular population, our results are suggestive, and provide a reference point for future studies. A limitation of this study is that it appears probable that our results were diluted due to the fact that we did not find any subjects who met our initial operational definition of childlessness, and therefore established a second, less rigorous criteria. It is noteworthy that we did not find any subjects in our population who met the original five year criteria for childlessness. There is no known reason the childless rate in the catchment area for the clinic would be below the national figures, particularly as this is an urban area. In addition there is nothing obvious in the policies or style of the clinic which would deter childless clients. Therefore, their absence from entry into this part of the mental health system remains unexplained. 
The most immediate application of this study appears to be in exposing the idea that non-parents are emotionally disturbed or maladjusted as unsupported and inaccurate. That this view is widespread is irresponsible and potentially dangerous and damaging. It appears possible that the strong social pressures reflected in negative views of non-parents, may push some adults into becoming parents, who otherwise would not have children. It is assumed that this may result in a legacy of dissatisfied and resentful parents, inadequate parenting, and subsequent emotional problems for their children. It would appear that reducing the pressure to have children, by exposing myths regarding non-parents, may be an important preventive measure. 


\section{SOURCES CONSULTED}

Arnold, Paul Derwood. "Marriage Counselee MMPI Profile Characteristics with Objective Signs That Discriminate Them From Married Couples In General." Dissertation $\mathrm{Ab}-$ stracts International, 32 (IB), (July 1971), 548 .

Bram, Susan. "To Have or Have Not: A Social Psychological Study of Voluntarily Childless Couples, Parents-To-Be, And Parents." Dissertation Abstracts International, $8 \mathrm{~B}$ (Feb. 1975), 4250 .

Chester, Robert. "Is There a Relationship Between Childlessness and Marriage Breakdown?" P. 114-126, in Ellen Peck and Judith Senderowitz (Ed.), Pronatalism (New York: Thomas Y. Crowell Company), $\overline{1974 .}$

Christensen, Harold T. "Children in the Family: Relationship of Number and Spacing to Marital Success." Journal of Marriage and the Family, Vol. 30, \#2 (1968), 283-289.

Cox, Nancy. "Pronatal Influences in Home Economics Texts in a Junior High School." P. 68-113, in Ellen Peck and Judith Senderowitz (Ed.), Pronatalism (New York: Thomas Y. Crowell Company), 1974.

Dahlstrom, W. Grant; Welsh, George Schlager; and Dahlstrom, Leona E. An MMPI Handbook Volume II: Research Applications. (Minneapolis: University of Minnesota Press), 1960 .

Das Gupta, Prithuies. "A Method of Computing Period Rates of Spinsterhood And Childlessness From Census Data Applied To The United States." Social Biology, Vol. 22, \#2 (1975), 134-146.

Drake, L. E.; and Oetting, E. R. An MMPI Codebook For Counselors. (Minneapolis: University of Minnesota Press), 1958 .

Erikson, Erik. Childhood And Society. (2nd Ed.) (New York: W. W. Norton \& Company, Inc.), 1963.

Graybill, Wilson E.; and Glick, Paul. "Demographic And Social Aspects of Childlessness: Census and Data." The Milbank Memorial Fund Quarterly, XXXVII, \#l (1959), $60-86$. 
Gustavus, Susan $0_{.}$; and Henley, James R., Jr. "Correlates of Voluntary Childlessness in A Select Population." Social Biology, Vol. 18, \#3 (1971), 277-284.

Kaij, L.; and Malmquist, A. "Motherhood and Childlessness In Monozygous Twins, Part I Early Relationships." British Journal of Psychiatry, Vol. 118, \#542 (1971), $11-28$.

Kenkel, William F. The Family In Perspective. (New York: Appleton - Century - Crofts, Inc.), 1960.

Le Masters, E. E. Parents In Modern American, A Sociological Analysis. (Homewood, Ill.: The Dorsey Press), 1970.

Malmquist, A.; and Kaij, L. "Motherhood and Childlessness In Monozygous Twins, Part II The Influence of Motherhood On Health." British Journal of Psychiatry, Vol. 118, \#542 (1971), 22-28.

Movius, Margaret. "Voluntary Childlessness - The Ultimate Liberation." Family Coordinator, Vol. 25, \#1 (1976), 57-64.

Murstein, Bernard I.; and Glaudin, Vincent. "The Use of The MMPI In The Determination of Marital Maladjustment." Journal of Marriage And The Family, Vol. 30, \#4 (1968), $651-655$.

Peck, Ellen; and Senderowitz, Judith (Ed.). Pronatalism. (New York: Thomas Y. Crowell Company), 1974.

Pohlman, Edward. "Burgess and Cottrell Data on 'Desire for Children': An Example of Distortion in Marriage and Family Textbooks?" Journal of Marriage and Family, vol. 30, \#3 (1968), 433-436.

- "Childlessness, Intentional And Unintentional." The Journal of Nervous and Mental Disease, Vol. 151, \#1 (1970), 2-12.

Veenhoven, Ruut. "Is there an innate need for children?" European Journal of Social Psychology, Vol. 4, \#4 $(1974), 495-501$.

Veevers, J. E. "Childlessness and Age at First Marriage." Social Biology, Vol. 18, \#3 (1971), 292-295.

"Differential Childlessness by Color: A Further Examination." Social Biology, Vol. 18, \#3 (1971), 285291 . 
"Factors in the Incidence of Childlessness in Canada: An Analysis of Census Data." Social Biology, Vol. 19, \#3 (1972), 266-274.

- "Parenthood And Suicide: An Examination of A Neglected Variable." Social Science \& Medicine, Vol. 7, \#2 (1973), 135-144.

"Rural - Urban Variation In The Incidence of Childlessness." Rural Sociology, Vol. 36, \#4 (1971), 547-553.

- "The Moral Career of Voluntarily Childless Wives: Notes on The Defense of A Variant World View." The Family Coordinator, Vol 24, \#4 (1975), 473-488.

"The Social Meanings of Parenthood." Psychiatry, Vol. 36, \#3 (1973), 291-310.

"Voluntary Childlessness: A Neglected Area of Family Study." The Family Coordinator, Vol. 22, \#2 (1973), 199-206.

- "Voluntarily Childless Wives: An Exploratory Study." Sociology And Social Research, Vol. 57, \#3 $(1973), 3 \overline{56-366 .}$

Welsh, George Schlager; and Dahlstrom, W. Grant (Ed.). Basic Readings on The MMPI In Psychology \& Medicine. (Minneapolis: University of Minnesota Press), 1956.

Westoff, Leslie; and Westoff, Charles. From Now to Zero. (Boston, Mass.: Little, Brown And Company), 1968.

Wyatt, Frederick. "Clinical Notes on The Motives of Reproduction." Journal of Social Issues, Vol. 23, \#4 $(1967), 29-\overline{56}$. 